\title{
TOWARDS A CONTEXT-SPECIFIC SCHOOL LEADERSHIP COMPETENCE FRAMEWORK: A CASE STUDY OF LATVIA
}

\author{
Ilze Saleniece \\ University of Latvia, Latvia \\ Dace Namsone \\ University of Latvia, Latvia \\ Līga Čakāne \\ University of Latvia, Latvia \\ Anete Butkēviča \\ University of Latvia, Latvia
}

\begin{abstract}
The aim of the study described in this research paper is to examine effective school leadership practices by applying topical research knowledge in the area to the current school leadership situation in Latvia. The study design consists of two main stages - literature analysis, and the analysis of the Latvian context (analysis of 21 interview with school leaders, document and artefact analysis). As a result, authors have arrived at conclusions about the relevant context-specific aspects in regard to the effective school leadership in Latvia. Keywords: educational/school leadership, school leadership's impact on student achievement, competence assessment and development.
\end{abstract}

\section{Introduction}

Latvia is undergoing a nation-wide curriculum reform in general education, with a focus on competency-based approach to learning and development of $21^{\text {st }}$ century skills (Namsone, 2018). The reform implementation will start in September 2020 in preschools, and September 2021 - in schools. The success of the reform implementation falls also on the shoulders of the school leadership. Fullan (2015) sees school principals as "change leaders", and emphasizes their key role in school improvement and reform implementation. A large body of research on school effectiveness and improvement highlights the impact of school leadership 
on student achievement (Leithwood, 2006, 2008; Hallinger, 2011; Waters, Marzano, McNulty, 2003). Evidence shows that school leadership is second only to classroom teaching in terms of the influence on student learning (Leithwood, Harris, Hopkins, 2008). In the context of the on-going educational reform, authors find it important to study the most significant school leadership practices that make a difference to student learning, with an aim to understand what "the right things to do" are to transition to the $21^{\text {st }}$ century teaching and learning. Furthermore, the research focuses on the leadership practices that are significant and specific to the local context, understanding that "the precise characteristics of [..] effective leadership [..] are context dependent" (Reynolds, Sammons, De Fraine, Van Damme, Townsend, Teddlie, Stringfield, 2014).

\section{Aim of the Study}

The purpose of the research is to arrive at the local context specific framework of school leadership practices which are significant in the context of student achievement. This will be achieved by looking into differences between the leadership practice domains and dimensions described in the research literature and the practice of school leaders in Latvia. As a result, the school leadership framework that is usable in the Latvian context will be created and described. This research sets the ground for a further work on the development of a conceptual framework of school leadership competence assessment in the Latvian context.

To achieve the purpose, the following research questions are set:

1. What are significant school leadership practices described in literature, existing frameworks and normative documents?

2. How school leadership practices defined in research literature manifest in school practice in Latvia?

\section{Theoretical Framework}

To compare leadership practices described in the literature with practices of school leaders in Latvia, authors have chosen the Framework of Key Leader Practices by Hitt and Tucker (2015) as the main reference point. This decision was based on the fact that this is a unified framework, developed by conducting a systematic review of 56 empirical research studies in the period from 2000 to 2014, and covering over 40 years of research on principal effectiveness and its relationship with student achievement. In addition to the empirical research, it also integrates three other known frameworks.

The strength of Hitt and Tucker's framework lies also in the fact that it focuses on leadership practices rather than characteristics. That is important 
for authors, considering the future goal to develop a working and local context specific school leadership competence assessment framework.

To ensure the comprehensiveness of the framework, authors additionally looked at the five other existing frameworks and guidelines describing impactful leadership practices: The Ontario Leadership Framework (developed by Kenneth Leithwood, 2012), The Australian Professional Standard for Principals and the Leadership Profiles (2015), The Wallace foundation Report (2013), The Framework of Reference by the European Qualification Network for Effective Leadership, (2011) and the OECD's Improving School Leadership - Policy and Practice in OECD Countries $(2008,2010)$. The summary of main domains or categories of various frameworks can be seen in the Table 1.

To have an overarching and all-encompassing view on the context of school leadership, as well as to gain greater understanding on the ways how school leadership influences student learning, authors used Hallinger's "Synthesized Model of Leadership for Learning" (2011), which is based on synthesis of 40 years of empirical leadership research. The added value of the model is that it organises various elements of "leadership for learning" in a system, thus explaining connections and hierarchies between them. The model emphasises that school and leadership sits in a certain context. Firstly, it is internal/school-level context, and secondly it is external context (community, country, society-level). It also indicates three core areas of leadership - setting vision and goals, development and implementation of academic structures and processes, and building people capacity. These all are well reflected in the frameworks described in the Table 1. Another important conclusion provided by the Hallinger's work is that the impact of school leadership on student learning is mostly indirect, i.e. through systems, procedures, people and the environment.

\section{Methodology}

This is a qualitative research, and it can be described by the following consecutive phases - review of the literature and building of an in-depth understanding of key areas of school leadership practice, school visits to interview school leadership and collect relevant materials and artefacts, interview and artefact analysis, additional document analysis, final development of the adapted framework of school leadership practices.

After the literature review, authors developed a set of interview questions, which matched the domains and dimensions of the chosen core framework by Hitt and Tucker (2015), and thus "the variables" of the interview were defined (Tuckman, 1972 in Cohen, Manion, Morrison, 2011). In total, 7 schools were visited and in each school three members of the leadership 


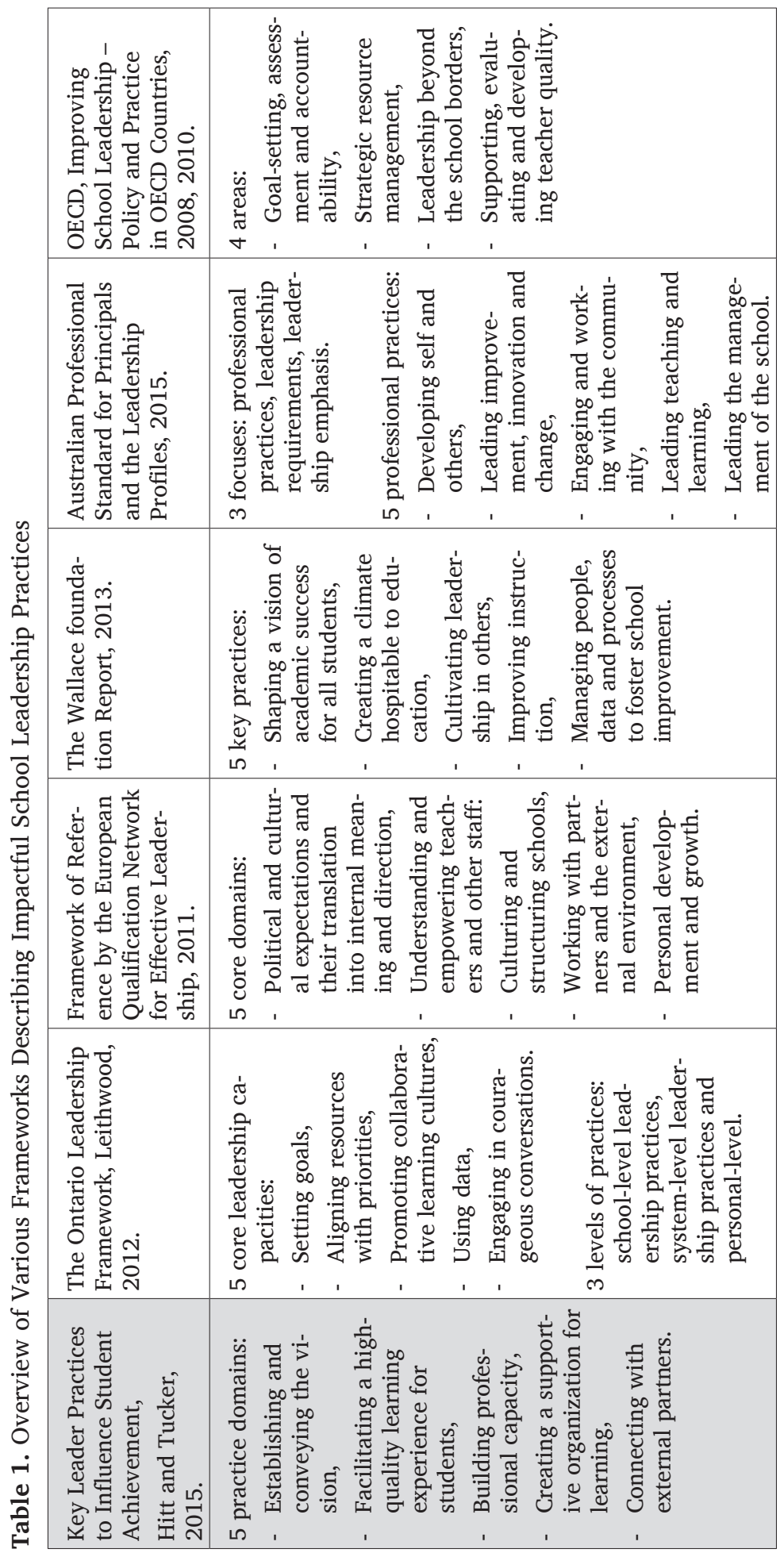


team were interviewed - the Head of the School and two Deputy Heads, thus in total 21 interview was conducted. The type of the interview was semi-structured. Although it had a set of pre-determined questions, when appropriate, interviewer allowed new themes to be brought up. Each interview was conducted by two researchers. One of them was leading the interview by asking the questions, and the other was making notes and following whether all relevant questions have been asked. Selected schools for the research were all general education schools of Valmiera city, which is the $8^{\text {th }}$ biggest city in Latvia, and is the economic, educational, cultural and administrative centre of the Vidzeme region. Selected school sample represent a moderate diversity of schools in terms of their size, student achievement, programmes, etc. The number of schools and the context of a specific city could be one of the limitations of the research.

In addition to interviews, school teams participated in a mapping exercise organised by the research team - they were asked to mark and describe the practice dimensions of the Hitt and Tucker's framework in the context of their own practices. Also, researchers were observing the school environment, and were taking pictures of the learning and public spaces of the school to use them for later analysis.

The interviews were analysed by identifying "natural units of meaning", which later were classified and categorized in order to structure the outline of each interview (Cohen, Manion, Morrison, 2011). At the final stage, the overall conclusions and interpretations were made, specifically paying attention to the themes that were occurring most frequently, themes that weren't covered enough (i.e. practice dimensions that weren't explored enough during the interview, as well as during the mapping exercise), and themes that fell outside the defined "borders" of Hitt and Tucker's framework.

As a result, all analysis were pulled together, and authors reviewed the Hitt and Tucker's framework and in a group discussion agreed on the necessary adaptations to the Latvian context, considering the gathered data through the research.

Apart from interview analysis, authors looked at relevant normative documents regulating both school assessment and the new curriculum reform.

\section{Results}

The second column of Table 2 indicates the adaptations authors made, following the outcomes of the qualitative research. To show the changes and aspects that are specific for the local context in contrast to the original framework, the respective text is bolded and underlined. 
Table 2. Two Frameworks: Hitt and Tucker's Framework (2015) and

The Adapted to the Latvian Context Version of the Hitt and Tucker's Framework

\begin{tabular}{|c|c|}
\hline $\begin{array}{c}\text { Hitt and Tucker's Framework of } \\
\text { Key Leader Practices to Influence } \\
\text { Student Achievement. } \\
\text { Domains and Dimensions. } \\
\end{array}$ & $\begin{array}{l}\text { Hitt and Tucker's Framework of Key Leader } \\
\text { Practices to Influence Student Achievement, } \\
\text { adapted to the Latvian context. } \\
\text { Domains and Dimensions. }\end{array}$ \\
\hline $\begin{array}{l}\text { 1. Establishing and conveying } \\
\text { the vision. }\end{array}$ & 1. Establishing and conveying the vision. \\
\hline $\begin{array}{l}\text { - Creating, articulating and } \\
\text { stewarding shared mission and } \\
\text { vision. }\end{array}$ & $\begin{array}{l}\text { - Creating, articulating and stewarding shared } \\
\text { mission and vision. }\end{array}$ \\
\hline $\begin{array}{l}\text { - Implementing vision by } \\
\text { setting goals and performance } \\
\text { expectations. }\end{array}$ & $\begin{array}{l}\text { - Implementing vision by setting specific and } \\
\text { learning-focused goals and performance } \\
\text { expectations, performance measurement } \\
\text { procedure and accountability. }\end{array}$ \\
\hline \multirow[t]{2}{*}{$\begin{array}{l}\text { - Communicating broadly the state } \\
\text { of the vision. }\end{array}$} & $\begin{array}{l}\text { - Communicating broadly and regularly } \\
\text { the state of the vision. }\end{array}$ \\
\hline & $\begin{array}{l}\text { Ensuring alignment between goals of } \\
\text { the school, school leadership and each } \\
\text { individual teacher. }\end{array}$ \\
\hline $\begin{array}{l}\text { - Modelling aspirational and } \\
\text { ethical practices. }\end{array}$ & - Modelling aspirational and ethical practices. \\
\hline $\begin{array}{l}\text { - Promoting use of data for } \\
\text { continual improvement. }\end{array}$ & $\begin{array}{l}\text { Has been broadened and moved to the domain } \\
\text { "Creating a supportive organization for learning". }\end{array}$ \\
\hline $\begin{array}{l}\text { - Tending to external } \\
\text { accountability. }\end{array}$ & $\begin{array}{l}\text { External contexts, as well as school's } \\
\text { local positioning and strengths are } \\
\text { considered in building vision and goals. }\end{array}$ \\
\hline $\begin{array}{l}\text { 2. Facilitating a high-quality } \\
\text { learning experience for } \\
\text { students. }\end{array}$ & $\begin{array}{l}\text { 2. Facilitating a high-quality learning } \\
\text { experience for students. }\end{array}$ \\
\hline $\begin{array}{l}\text { - Maintaining safety and } \\
\text { orderliness. }\end{array}$ & - Maintaining safety and orderliness. \\
\hline \multirow[t]{2}{*}{$\begin{array}{l}\text { - Personalizing the environment to } \\
\text { reflect students' background. }\end{array}$} & $\begin{array}{l}\text { - Creating the environment to reflect } \\
\text { students' background and school as } \\
\text { organization for learning. }\end{array}$ \\
\hline & $\begin{array}{l}\text { - Promoting wellbeing and inclusive } \\
\text { education. }\end{array}$ \\
\hline \multirow[t]{2}{*}{$\begin{array}{l}\text { Developing and monitoring } \\
\text { instructional program. }\end{array}$} & $\begin{array}{l}\text { - Developing and monitoring curriculum } \\
\text { implementation. }\end{array}$ \\
\hline & $\begin{array}{l}\text { - Developing and monitoring teaching and } \\
\text { learning (instructional program) that } \\
\text { address needs and growth of every } \\
\text { student. }\end{array}$ \\
\hline \multirow[t]{2}{*}{$\begin{array}{l}\text { - Developing and monitoring } \\
\text { assessment program. }\end{array}$} & $\begin{array}{l}\text { - Developing and monitoring assessment } \\
\text { program. }\end{array}$ \\
\hline & - Buffering staff from distractions. \\
\hline
\end{tabular}




\begin{tabular}{|c|c|}
\hline 3. Building professional capacity. & 3. Building professional capacity. \\
\hline - Selecting for the right fit. & $\begin{array}{l}\text { - Selection and retention of high quality } \\
\text { teaching staff. }\end{array}$ \\
\hline $\begin{array}{l}\text { Providing opportunities to learn } \\
\text { for whole faculty, including } \\
\text { leader(s). }\end{array}$ & $\begin{array}{l}\text { Building effective system for learning } \\
\text { needs assessment and providing } \\
\text { appropriate continuous learning } \\
\text { opportunities for all staff, including } \\
\text { leader(s). }\end{array}$ \\
\hline $\begin{array}{l}\text { - Providing individualized } \\
\text { consideration. }\end{array}$ & $\begin{array}{l}\text { Providing individualized approach to } \\
\text { performance management and learning } \\
\text { and development. }\end{array}$ \\
\hline $\begin{array}{l}\text { - Creating communities of } \\
\text { practice. }\end{array}$ & $\begin{array}{l}\text { Embedding systems for exchanging } \\
\text { knowledge and learning, and ensuring } \\
\text { learning's transfer in practice. }\end{array}$ \\
\hline $\begin{array}{l}\text { - Engendering responsibility for } \\
\text { promoting learning. }\end{array}$ & $\begin{array}{l}\text { - Creating a culture of learning and } \\
\text { development. }\end{array}$ \\
\hline $\begin{array}{l}\text { - Supporting, buffering, and } \\
\text { recognizing staff. }\end{array}$ & $\begin{array}{l}\text { - Demonstrating active position in } \\
\text { supporting and recognizing staff. }\end{array}$ \\
\hline - Building trusting relationships. & $\begin{array}{l}\text { - Building trusting and cooperative } \\
\text { relationships. }\end{array}$ \\
\hline $\begin{array}{l}\text { 4. Creating a supportive } \\
\text { organization for learning. }\end{array}$ & $\begin{array}{l}\text { 4. Creating a supportive organization for } \\
\text { learning. }\end{array}$ \\
\hline $\begin{array}{l}\text { - Maintaining ambitious and high } \\
\text { expectations and standards. }\end{array}$ & $\begin{array}{l}\text { - Maintaining ambitious and high } \\
\text { expectations and standards. }\end{array}$ \\
\hline $\begin{array}{l}\text { - Acquiring and allocating } \\
\text { resources strategically for } \\
\text { mission and vision. }\end{array}$ & $\begin{array}{l}\text { - Acquiring, allocating and managing } \\
\text { resources strategically in support of } \\
\text { the school's vision and goals. }\end{array}$ \\
\hline $\begin{array}{l}\text { - Considering context to maximize } \\
\text { organizational functioning. }\end{array}$ & $\begin{array}{l}\text { - Considering context to maximize } \\
\text { organizational functioning. }\end{array}$ \\
\hline $\begin{array}{l}\text { - Building collaborative processes } \\
\text { for decision making. }\end{array}$ & \multirow[t]{2}{*}{$\begin{array}{l}\text { - Building collaborative processes for decision } \\
\text { making and distributing leadership. }\end{array}$} \\
\hline $\begin{array}{l}\text { - Sharing and distributing } \\
\text { leadership. }\end{array}$ & \\
\hline $\begin{array}{l}\text { - Tending to and building on } \\
\text { diversity. }\end{array}$ & - Tending to and building on diversity. \\
\hline \multirow[t]{3}{*}{$\begin{array}{l}\text { - Strengthening and optimizing } \\
\text { school culture. }\end{array}$} & $\begin{array}{l}\text { - Strengthening and optimizing school culture } \\
\text { and values. }\end{array}$ \\
\hline & - Leading innovation and change. \\
\hline & $\begin{array}{l}\text { Promoting use of data and building } \\
\text { systems for evidence-based decision } \\
\text { making and effective data management. }\end{array}$ \\
\hline $\begin{array}{l}\text { 5. Connecting with external } \\
\text { partners. }\end{array}$ & $\begin{array}{l}\text { 5. Building relationships with local } \\
\text { community and external partners. }\end{array}$ \\
\hline $\begin{array}{l}\text { - Building productive relationships } \\
\text { with families and external } \\
\text { partners in the community. }\end{array}$ & $\begin{array}{l}\text { - Building productive relationships } \\
\text { with families and external partners in } \\
\text { the community (NGOs, companies etc.). }\end{array}$ \\
\hline
\end{tabular}




\begin{tabular}{|c|c|}
\hline $\begin{array}{l}\text { Engaging families and } \\
\text { community in collaborative } \\
\text { processes to strengthen student } \\
\text { learning. }\end{array}$ & $\begin{array}{l}\text { Engaging families and community in } \\
\text { collaborative processes to support and } \\
\text { strengthen student learning. }\end{array}$ \\
\hline \multirow{3}{*}{$\begin{array}{l}\text { - Anchoring schools in } \\
\text { the community. }\end{array}$} & - Anchoring schools in the community. \\
\hline & $\begin{array}{l}\text { Partnership with local and national } \\
\text { authorities and organizations/ } \\
\text { institutions significant for school } \\
\text { improvement (municipality, ministry, } \\
\text { agencies, etc.). }\end{array}$ \\
\hline & $\begin{array}{l}\text { - Networking with other schools and } \\
\text { organisations for learning at national, } \\
\text { international level. }\end{array}$ \\
\hline
\end{tabular}

\section{Discussion}

The discussion is organised into sections according to the five domains of key leader practices identified in the systematic review by Hitt and Tucker (2015). Each section focuses on the aspects that are critical and relevant for the Latvian context. The suggested changes in the original framework and local context specific adaptations are described and discussed.

At the end of the chapter, the overall conclusions are drawn and further research ideas are presented.

\section{Establishing and conveying the vision}

Keeping in mind that the overall aim of the framework is to identify school leadership practices that are significant for school improvement and student achievement, it is crucial to underline the need for goals of the school to be focused on learning. Interviews indicate that goals that are set are not always clear and specific enough, as well as centred on student learning. Hallinger (2011) emphasises the essential role school leadership plays in directing and maintaining the focus of school's vision and goals on learning.

Considering that several research synthesis (Hallinger and Heck, 1996; Robinson et al., 2008) point out that vision and goals is the most important lever in hands of the leadership to influence student learning, authors add to the framework a new dimension "Ensuring alignment between goals of the school, school leadership and each individual teacher", thus highlighting school leadership's role in building a coherent and hierarchical structure of goals within the organisation. Interviews provide an insight into importance of aligning the goals of school with those of leadership and each individual teacher. In several cases, members of leadership team gave different answers to the question about the goals of the school, their own goals and 
goals for the teaching staff, illustrating that there are inconsistencies in internal goal alignment. The lack of clarity can negatively contribute to teacher motivation and commitment, and Leithwood and Jantzi (2006) emphasise that the motivation of school staff is particularly important for large-scale reforms to be successful.

Furthermore, interviews suggest the need for an active position of school leadership with regard to setting performance expectations and building and overseeing performance measurement. This goes in line with the need for school to have an adequate capacity in data-based decision making, planning and data management in general.

Interviews also show that school leaders are aware of external expectations and pressures, such as current curriculum reform and regulations defining changes regarding teaching and learning. They are also clear about their school's strengths and unique position in the local area. However, it can be concluded, that not always this useful knowledge on external and local contexts inform vision and goals that schools are setting and implementing. Authors see the need to strengthen this as one of the significant practices of school leadership in Latvia, and emphasise the need for school leaders to be the mediators between the external and internal contexts, able to "translate external requirements into internal meaning" (Framework of Reference by the European Qualification Network for Effective Leadership, 2011).

\section{Facilitating a high-quality learning experience for students}

Considering the significance of leadership practices related to highquality learning experience for students, authors have suggested several adaptations.

Firstly, authors have added a dimension related to curriculum implementation. The on-going curriculum reform and respective changes in regulations foresee that schools have greater autonomy in the way they plan the delivery of curriculum, and the learning content is not organized in subjects, as previously, but in broader learning areas. Thus, there is a need for school level planning of subject teaching, taking into account school's specific situation, needs, and resources, for example, what subjects each teacher is teaching. The organization and monitoring of this process falls under the responsibility of school administration. In their research, Leithwood and Jantzi (2006) draw attention to the conclusion that school leadership has a significant influence on teacher classroom practices, and the possibility of these practices to be altered.

As regards assessment, the curriculum reform has an emphasis on formative assessment and its effective implementation (Čakāne, 2018). As most interviews indicate, primarily the assessment program is understood 
in the context of summative assessment and results. There is a need for the development of systems and practices that promote effective use of formative assessment and diagnostic data, with an aim to better understand the necessary improvements in teaching and learning, and thus helping students' progress. In order to ensure successful reform implementation, it is highly important to set this as one of the key focus areas for school leadership.

Interviews with school leaders lead to an understanding that teachers have comparatively many obligations and are involved in various activities besides their teaching, for example, they are organising and participating in various events. The Ontario Leadership Framework under the domain "Improving the Instructional Program" has a dimension "Buffering staff from distractions to their work". Considering the local context and interview results, authors have included this dimension in the adapted version of the framework, thus signalling the need for school leadership to enable teachers to have full focus on instruction, and address the role of leadership in buffering and protecting their staff from unnecessary bureaucratic and time-consuming activities that aren't directly linked to their job and the high-quality learning and teaching.

Taking into account the OECD's PISA 2015 results, illustrating challenges for Latvian schools with regard to students' exposure to bullying and students' sense of belonging at school, by perception of teacher support, authors have added to this domain of the framework a contextrelevant dimension concerning school leadership's practices to promotion of wellbeing and inclusive education. Furthermore, interviews indicate that there is a crucial need for strengthening the dimension of inclusive education and supporting learning and development of every child. In their answers about school's success, several school leaders celebrate the achievement of few top-performers instead of continuous growth of every student. Also, the lack of knowledge and experience, as well as resources to deliver differentiated instruction and assessment is mentioned as one of the areas for improvement. Research proves, however, that schools can improve student learning outcomes despite the various starting points, and that leadership through modelling central organizational processes plays a critical role in this regard (Hallinger, 2011).

Field notes from school visits, photos taken at schools, as well as interviews suggest that some schools are using their physical environment more effectively than others to communicate that school has a specific audience - young people and a specific goal - their learning. For example, some schools have an informal space for learning outside the classroom, as well as space for resting and free time activities. The equipment and furniture is suitable and comfortable for the students. Also, authors 
paid attention to how schools use their space outside the classrooms to communicate students' learning, i.e. how they are using walls, corridors, entrance area and any other public space school has. As a result, the respective dimension is paraphrased as "Creating the environment to reflect students' background and school as organization for learning". It can be suggested that this contributes to students' sense of belonging and thus their general wellbeing at the school.

\section{Building professional capacity}

Interviews suggest that there is a lack of procedures on how learning needs are assessed and what the role of the leadership is in this regard. Overall, teachers are actively involved in various learning activities and trainings, however, in most of the cases their learning is dependent on the supply, i.e. what training is being offered, and it isn't necessarily needs-driven approach. Following school leadership reflections on the comparatively low effectiveness of learning, authors have paraphrased the dimension, by emphasising that learning of the staff should be based on their actual and specific needs. This helps to design appropriate learning solutions for the professional capacity building of the staff.

It is important to provide tailor-made and individualised professional development solutions, tackling the exact areas for improvement. Furthermore, authors see that learning should be linked to the individual performance goals of the staff, the necessary competence development, as well as monitoring of the progress. This is confirmed also by the Australian Professional Standard for Principals (2015). Although some of the interviewed school leaders mentioned the practice of yearly performance assessment through school administration's conversation with each individual teacher, there is a need for a more systemic and strategic development of performance management and planning of individual learning and development.

Authors have broadened the formulation of the domain "Creating communities of practice". In the Latvian context the "communities of practice" mostly manifest in so called methodological committees that are organized either around subjects or learning areas. Interview results show, however, that they are predominantly communities of information transfer and focus on effective information flow that is characteristic to hierarchical management structures. Considering that the curriculum reform focuses on "school as a learning organisation" (OECD, 2016), with highly collaborative, learning orientated culture and student learning and achievement as it's primarily goal, there is a need for building systems and effective ways how staff learning and best practice exchange can add value and transform their performance. Also, authors want to stress the importance of knowledge transfer into practice. As a result, the context-relevant dimension "Embedding 
systems for exchanging knowledge and learning, and ensuring learning's transfer in practice" has been developed. In their research on teacher effectiveness, Muijs, Kyriakides, Werf, Creemers, Timperley, Earl (2014) highlight the need for the "shifts in thinking", and outline the need for "collaborative inquiry based on the principles of self-regulated learning" instead of simple information exchange.

\section{Creating a supportive organization for learning}

As regards leadership practices related to creating a supportive organization for learning, apart from several rather minor additions and changes, authors have added two new dimensions to the original framework - "Leading innovation and change" and "Promoting use of data and building systems for evidence-based decision making and effective data management". Leading innovations and change is mentioned in the Australian Professional Standard for Principals, 2015, and authors find this as a relevant leadership practice, considering the ongoing curriculum reform. Most of the interviews indicate leadership's awareness of the necessity to manage change, however only few are taking an active leadership position in this regard.

Such leadership practices as data usage in monitoring instruction and assessment and data-driven decision making and planning, are crucial for the Latvian context and relevant for a successful implementation of the reform. Interviews indicate that leaders aren't actively using data in their work, and many of them are at the beginning level of the data competency, i.e. either making decisions that aren't based on data or aren't able to make an effective use of and apply the available data (Cech, Spaulding, Cazier, 2018). Also, the Australian Professional Standard for Principals (2015) highlights the need for school leadership to "use a range of data management methods and technologies to ensure that the school's resources and staff are efficiently organised and managed to provide an effective and safe learning environment as well as value for money".

\section{Building relationships with local community and external partners}

The original leadership framework domain "Connecting with external partners" has been broadened as well, and authors have included two significant partnership areas - partnership with the local and national authorities, and partnership with other schools. This goes in line with the Framework of Reference by the European Qualification Network for Effective Leadership (2011), and the results of the interviews. In their answers, school leaders emphasised the significance of the support from the local authority (methodological and professional development support, resource-related support, strategic guidelines, funding, social 
support programmes for certain groups of students, etc.). Also, various perceptions on relationship and power distribution between schools and the municipality were observed; some leaders believed they have an impact on the decisions taken at the municipality level and saw the municipality as their partner; at the same time some leaders believed that the municipality has the power over their development and they have little or no impact on the decisions that are taken at the municipality level. Thus, the schoolmunicipality relationship is a specific and relevant aspect to consider in the Latvian context.

In addition to the interview analysis, the analysis of documents was conducted. There are two main conclusions stemming from the review of the documents. Firstly, the documents regulating the new curriculum and its implementation in general education are in line with the leadership practices described in the framework and the adaptations that were made support the reform implementation. Also, the educational reform utilizes the OECD's concept "school as a learning organization", that aligns and covers almost all domains of the framework.

As regards the normative documents for school and leadership assessment, it can be concluded that key school leadership competences identified in the document overlap with the competences of the framework; however, they lack the detail and angle specific for the implementation of the reform goals. Furthermore, the assessment is conducted once every 6 years, and its primary aim is to assess staff's suitability for the position. As regards the method of assessment, school leaders are assessed through an electronic performance assessment system that is based on their selfassessment, and thus the objectivity of the assessment can be questioned. The framework that authors aim to develop has an emphasis on learning and development of the leadership, and provision with clear instructions, examples and ways how they could improve their practices, in order to improve student achievement. Also, authors see the need for development of assessment methods of school leadership practices.

\section{Conclusion and Further Work}

Overall, it can be concluded that conducted interviews and study of relevant materials and artefacts, have provided authors an insight that the existing frameworks, describing leadership practices that influence student achievement, should be adapted to the local realities. Furthermore, the need for adaptations applies to all domains and levels of leadership practices. At the same time, the Hitt and Tucker's framework served as a valid backbone structure to test and analyse educational contexts specific to Latvian schools. 
The key local specifics refer to the school leadership's responsibility and action towards clear and learning-focused vision and goals; data-driven performance assessment and management systems; specific programs for learning, teaching and assessment with an aim to improve every student's achievement; individualized learning and professional development systems; relationship building with student families, community and relevant external partners.

Considering the current curriculum reform and the role leadership plays in influencing student achievement, this research provides a useful road map for schools to become more effective. Further research can focus on detailed description of each dimension by identification of indicators that characterise the lowest and the highest value of the dimension, i.e. two extreme values. Additionally, examples illustrating those values at various levels (the lowest, the highest) can be gathered from the local schools. As a result, the further steps would lead to the development of locally relevant School Leadership Competence Assessment Framework, helping schools to improve and manage their development.

\section{References}

Cech, Thomas G., Spaulding, Trent J., Cazier, Joseph A. (2018) "Data competence maturity: developing data-driven decision making", Journal of Research in Innovative Teaching \& Learning, Vol. 11 Issue: 2, pp. 139-158, https://doi.org/10.1108/ JRIT-03-2018-0007.

Cohen, L., Manion, L. and Morrison, K. (2011). Research Methods in Education. $6^{\text {th }}$ ed. New York: Routledge.

Čakāne, L., (2018). Strenghtening of formatinve assessment in implementing deep learning. https://doi.org/10.22364/ml.2018.5

Fullan, M. (2015). The new meaning of educational change. $5^{\text {th }}$ edition. New York: Teachers College Press.

Hallinger, Philip (2011) "Leadership for learning: lessons from 40 years of empirical research", Journal of Educational Administration, Vol. 49 Issue: 2, pp. 125-142, https:// doi.org/10.1108/09578231111116699.

Leithwood, Kenneth, Jantzi, Doris (2006) Transformational school leadership for large-scale reform: Effects on students, teachers, and their classroom practices, School Effectiveness and School Improvement, 17:2, 201-227, DOI: $10.1080 / 09243450600565829$.

Leithwood Kenneth, Harris, Alma, Hopkins, David (2008) Seven strong claims about successful school leadership, School Leadership and Management, 28:1, 27-42, DOI: 10.1080/13632430701800060.

Muijs, Daniel, Kyriakides, Leonidas, Werf, Greetje van der, Creemers, Bert, Timperley, Helen \& Earl, Lorna (2014) State of the art - teacher effectiveness and professional learning, School Effectiveness and School Improvement, 25:2, 231-256, DOI: 10.1080/09243453.2014.885451. 
Namsone, D. (Scientific Editor) (2018). Learning for Competence (Mācīšanās lietpratībai). Riga: University of Latvia Academic Publishing. DOI: https://doi. org $/ 10.22364 / \mathrm{ml} .2018$.

PISA 2015 Results (Volume III), Students' Well-Being, OECD Publishing, 2017, https:// dx.doi.org/10.1787/9789264273856-en.

Reynolds, David, Sammons, Pam, De Fraine, Bieke, Van Damme, Jan, Townsend, Tony, Teddlie, Charles \& Stringfield, Sam (2014) Educational effectiveness research (EER): a state-of-the-art review, School Effectiveness and School Improvement, 25:2, 197-230, DOI: $10.1080 / 09243453.2014 .885450$.

The Australian Professional Standard for Principals, 2015. Australian Institute for Teaching and School Leadership.

The Making of Leadership in Education: A European Qualification Network for Effective School Leadership, NLQ Hildesheim, 2011, http://www.leadership-in-education.eu/ fileadmin/Framework/EN_Framework.pdf.

The Ontario Leadership Framework with a Discussion of the Research Foundations. 2012. The Institute for Education Leadership.

The Wallace Foundation Report "The School Principal as Leader: Guiding Schools to Better Teaching and Learning", 2013. The Wallace Foundation.

Waters, Tim, Marzano, Robert J., McNulty, Brian (2003). Balanced Leadership: What 30 Years of Research Tells Us about the Effect of Leadership on Student Achievement. A Working Paper. Mid-Continent Regional Educational Lab., Aurora, CO. 21 p. 